\title{
Accumulation and Fractionation of Iron and Copper in Urban and Rural Soil from Brazilian City
}

\author{
Aline Pereira de Oliveira, Caíque Matheus Santos Pereira Noda, Juliana Naozuka $\mathbb{D}$ \\ Departamento de Química, Universidade Federal de São Paulo, Rua Prof. Arthur Riedel, 275, 09972-270, \\ Diadema, SP, Brasil
}

Graphical Abstract

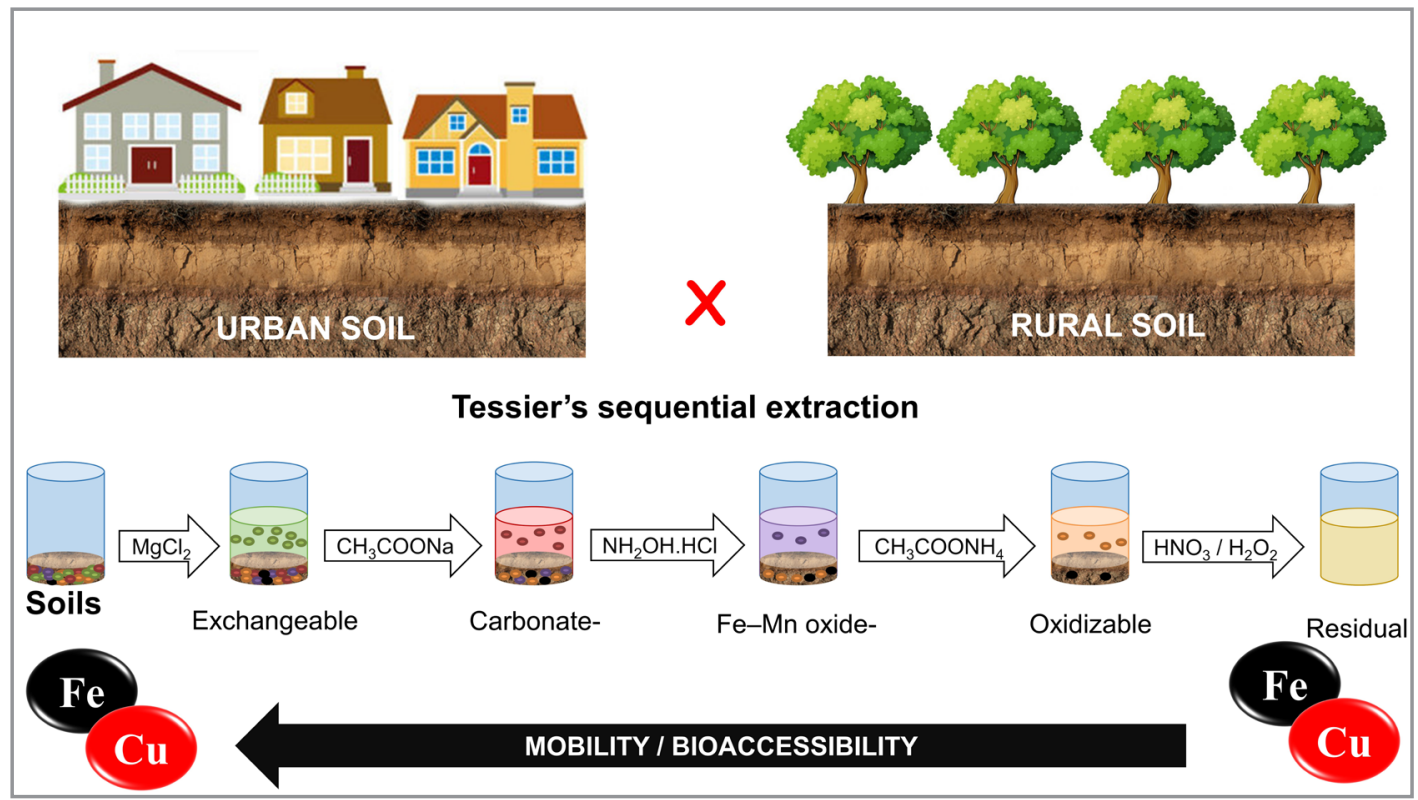

The anthropic action effects on soil contamination with regard to Fe and $\mathrm{Cu}$ accumulation were evaluated through procedures to determine the pseudo-total concentration and fractionation based on elemental mobility and bioaccessibility in soils from rural and urban area collected in different depths.

Iron (Fe) and copper ( $\mathrm{Cu}$ ) are essential elements and naturally present in soils. However, these metals content can be altered by natural phenomena and/or anthropic actions, causing changes in the ecological balance. The anthropic actions effects on soil contamination with respect to Fe and $\mathrm{Cu}$ accumulation were evaluated through procedures to determine the pseudo-total concentration and fractionation by sequential extraction procedure in soils from a rural and urban area collected in different depths, which the fractions were experimentally defined as exchangeable, carbonate-, reducible (FeMn oxide-), oxidizable (organic matter and sulfites-bound) and residual. Results showed that pseudototal $\mathrm{Cu}$ concentrations were 13.7 and 10.5 times and Fe concentrations were 2.8 and 1.5 times higher in the urban area at depths of 5 and $15 \mathrm{~cm}$, respectively, than rural area. The fractionation evidenced the anthropic effects in the different elemental species. In general, the $\mathrm{Cu}$ and Fe distribution into the various solid phases showed similar patterns for each sample, which followed order: residual $>$ bound to organic matter $>$ bound to Fe-Mn oxides $>$ bound to carbonates $>$ exchangeable. Nevertheless, the $\mathrm{Cu}$ concentration in the fractions exchangeable and bound to carbonates in the rural soil collected at the depth of $15 \mathrm{~cm}$ were significantly higher in relation to the depth of $5 \mathrm{~cm}$, while there was no significant difference between $\mathrm{Cu}$ concentrations in other fractions at both depths evaluated. On the other hand, unlike that observed in the rural area, in the urban area the fractions of Cu exchangeable (fraction 1) and bound to carbonates (fraction 2) decreased significantly with increasing depth from 5 to $10 \mathrm{~cm}$. In 
addition, it was observed that significant $\mathrm{Cu}$ and $\mathrm{Fe}$ amounts were associated with the residual fraction in the soil from both regions, ranging from $20 \%(\mathrm{Cu}$ : rural, $15 \mathrm{~cm}$ ) to $91 \%$ (Fe: urban, $15 \mathrm{~cm}$ ) in relation to the pseudo-total concentration.

Keywords: Iron, copper, fractionation, soil, urban, rural

\section{INTRODUCTION}

In addition to several other components, such as quartz, feldspar, sand, silt and clay, the soil is composed of essential micro and macronutrients essential for living organism. However, soils of urban origin have meanwhile a variable composition, due to the significant amount of anthropogenic activities in urbanized areas and consequently higher contaminants levels in relation to soils of rural origin [1]. Nowadays, the soil contamination by metals, such as $\mathrm{Cu}, \mathrm{Fe}, \mathrm{Ni}, \mathrm{Cd}, \mathrm{Cr}, \mathrm{Pb}, \mathrm{Zn}$, is one of the main environmental problems [2,3]. Anthropogenic contamination of soils from industrial activities has been highlighted in recent years, in which metals are believed to be easily accumulated at the soil surface resulting in problems, such as toxicity to living organisms, food chain and ecosystem disruption $[4,5]$.

Among the micronutrients present in the soil are iron $(\mathrm{Fe})$ and copper $(\mathrm{Cu})$, which may be naturally present due to weathering and other soil formation processes [6]. However, the concentration of these metals in the soil can be altered by natural phenomena, such as elemental redistribution by wind and water or anthropic actions by residues burning and industrial dust deposition [2,5-8]. According to Brazilian legislation in the CONAMA resolution 420/2009 guideline values for Cu range from 200 (agricultural area) to 600 (industrial area) $\mathrm{mg} \mathrm{kg}^{-1}$ (dry mass), while for Fe there are no established data [9]. Indeed, high amounts of these metals may result in inhibition of plant growth causing changes in flora and microorganisms [10-12]. The high concentrations of Fe may be hazardous by catalyzing the production of oxygen radicals and stimulating the growth of bacteria, whereas Cu has high affinity for sulfur and nitrogenous ligands and in high concentrations can bind to important proteins sites [13,14].

Considering the information, it is necessary to improve understanding of the metal behavior in soils and the anthropic action effects on the metal distribution. Furthermore, the knowledge of the metals pseudototal concentration in soils is not enough in the evaluation of the their mobilities and bioavailabilities for living organisms. The mobility, bioavailability and toxicity of the pollutants depend on the chemical form and its binding state, in which fractionation methods from sequential extraction procedures can provide information on the metal associations with different soil geochemical phases [15-17].

Even with a wide variety of sequential extraction procedures currently available [18], Tessier's procedure [15] can be highlighted, which has been applied successfully in studies of soils and sediments [19-23]. The elemental fractionation procedure proposed by Tessier indicates that metals can be associated with different soil fractions and after sequential extraction procedures exchangeable, carbonate-related, reduced (associated with Fe or Mn oxides), oxidized (associated with organic matter) and residual fractions are obtained [15]. In general, the exchangeable form was considered readily mobile and bioavailable species, while the residual form was considered to incorporate into soil minerals and appeared to be the most inactive species. Bound to carbonate, Fe-Mn oxide and organic matter fractions can be considered relatively active depending on the physical-chemical properties of the soil $[15,18]$.

Although several single and sequential extractions methods have been proposed, the soil fractionation schemes were not standardized, and the results of different procedures are not always comparable, due to the lack of uniformity of the experimental conditions. On the other hand, a certain procedure can be applied successfully for comparison of soils from different areas to evaluate the anthropic actions effect on the metal species distribution and, consequently, elemental mobility and bioavailability in the environment. Thus, the aim of this study was to apply sequential extraction procedure (Tessier's procedure) to fractionate $\mathrm{Cu}$ and Fe content in rural soil, from an area of environmental preservation, and urban soil near to an industrialized area. 


\section{MATERIALS AND METHODS Instrumentation}

For quantification of Fe (pseudo-total and fractionated) and $\mathrm{Cu}$ (pseudo-total), an atomic absorption spectrometer (Model AAS Vario 6, Analytik Jena AG, Jena, Germany), equipped with a hollow cathode lamp of $\mathrm{Cu}(324.8 \mathrm{~nm}, 4 \mathrm{~mA}$, and slit $0.8 \mathrm{~nm})$ and $\mathrm{Fe}(248.3 \mathrm{~nm}, 4 \mathrm{~mA}$, and $0.8 \mathrm{~nm})$, and a deuterium lamp for background correction, was used. For elemental determination by flame atomic absorption spectrometry (F AAS), flame composition and observation height were optimized. The instrumental parameters were: for Fe, $70 \mathrm{~L} \mathrm{~h}^{-1}$ acetylene flow, $430 \mathrm{~L} \mathrm{~h}^{-1}$ air flow, and $5 \mathrm{~mm}$ observation height; and for $\mathrm{Cu}, 50 \mathrm{~L} \mathrm{~h}^{-1}$ acetylene flow, $430 \mathrm{~L} \mathrm{~h}^{-1}$ air flow, and $5 \mathrm{~mm}$ observation height.

For the Cu quantification in (i) exchangeable, (ii) bound to carbonates, (iii) bound to Fe-Mn oxides, (iv) bound to organic matter, and ( $v$ ) residual fractions, a ZEEnit 60 model atomic absorption spectrometer (Analytikjena AG, Jena, Germany) equipped with a transversely heated graphite atomizer, pyrolytically coated graphite tube, and transversal Zeeman-effect background correction was used. The spectrometer was operated with a hollow cathode lamp operated by a wavelength lamp current and slit equal to 324.8 $\mathrm{nm}, 4 \mathrm{~mA}$, and $0.8 \mathrm{~nm}$, respectively. All measurements were based on integrated absorbance values. A $10 \mu \mathrm{L}$ aliquot of different supernatants was introduced into the graphite tube without adding a chemical modifier. The instrumental conditions for the spectrometer and the heating program are shown in Table I. Argon 99.998\%, v v ${ }^{-1}$ (Air Liquide Brazil, SP, Brazil) was used as a protective and purging gas.

Table I. Heating program for Cu determination by GF AAS

\begin{tabular}{lcccc}
\hline Step & Temperature $\left({ }^{\circ} \mathrm{C}\right)$ & Ramp $\left({ }^{\circ} \mathbf{C ~ s}{ }^{-1}\right)$ & Hold $(\mathbf{s})$ & Argon flow $\left(\mathrm{mL} \mathrm{min}^{-1}\right)$ \\
\hline Drying & 130 & 5 & 20 & 1000 \\
Pyrolysis & 1200 & 100 & 15 & 1000 \\
Atomization & 2300 & 2300 & 5 & 0 \\
Cleaning & 2500 & 200 & 2 & 1000 \\
\hline
\end{tabular}

The samples were dried using an oven (model 515, FANEM, Brazil). An orbital shaker (Quimis, Brazil) was used to mix the samples and extractants. Phase separation was performed by centrifugation (Spectrafuge 6C Compact model, Labnet International, USA). The digestion of samples was carried out in a thermostatic water-bath (Q226M2 model, Quimis, Brazil).

\section{Reagents and samples}

The soil samples were collected in two different regions (urban or rural) and depths (5 and $15 \mathrm{~cm}$ ) from the city of Campo Limpo Paulista, SP, Brazil. Souza (2018) previously described the soil characteristics of a region close to our experimental area. It is a red clay soil, with loamy texture composed of sand $\left(45 \% \mathrm{w} \mathrm{w}^{-1}\right)$, silt $\left(25 \% \mathrm{w} \mathrm{w}^{-1}\right)$ and clay $\left(30 \% \mathrm{w} \mathrm{w}^{-1}\right), 2.82 \%\left(\mathrm{w} \mathrm{w}^{-1}\right)$ of organic matter with $\mathrm{pH}=4.9$ [24].

All solutions were prepared using analytical reagent-grade chemicals, with high-purity deionized water obtained from a Milli-Q water purification system (Millipore, USA). Analytical grade $65 \%\left(\mathrm{w} \mathrm{v}^{-1}\right)$ $\mathrm{HNO}_{3}$ (Merck, Germany), distilled in a quartz sub-boiling still (Marconi, Brazil), $30 \%\left(\mathrm{w} \mathrm{v}^{-1}\right) \mathrm{H}_{2} \mathrm{O}_{2}$ (Merck, Germany), and 37\% ( $\left.\mathrm{v} \mathrm{v}^{-1}\right) \mathrm{HCl}$ (Merck, Germany), were used for sample digestion and analytical solutions.

Analytical-grade Tritisol solutions (Merck, Germany) of $1000 \mathrm{mg} \mathrm{L}^{-1}$ for $\mathrm{Cu}\left(\mathrm{CuCl}_{2}\right)$ and $\mathrm{Fe}\left(\mathrm{FeCl}_{3}\right)$ were applied to prepare the reference analytical solutions, after dilution in $\mathrm{HNO}_{3} 0.1 \%\left(\mathrm{v} \mathrm{v}^{-1}\right)$ for determining the Fe and $\mathrm{Cu}$ content by $\mathrm{F} \mathrm{AAS}$ and graphite furnace atomic absorption spectrometry (GF AAS).

For the fractionation procedure solutions of $\mathrm{MgCl}_{2} \cdot 6 \mathrm{H}_{2} \mathrm{O}$ (Merck, Germany), $\mathrm{CH}_{3} \mathrm{COONa} 3 \mathrm{H}_{2} \mathrm{O}$ (Merck, Germany), $\mathrm{CH}_{3} \mathrm{COOH}$ (Sigma Aldrich, USA), $\mathrm{NH}_{2} \mathrm{OH} . \mathrm{HCl}$ (Synth, Brazil), and $\mathrm{CH}_{3} \mathrm{COONH}_{4}$ 
(Merck, Germany) were used.

\section{Soil sampling and preliminary sample preparation}

For soil sampling two different regions were sampled: rural (environmental preservation region) and

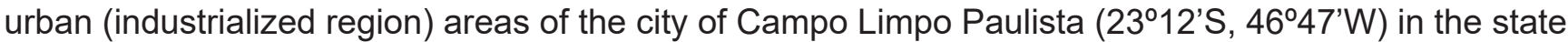
of Sao Paulo, Brazil, in which soil samples (six sub-samples) were randomly collected in an area of $2 \mathrm{x}$ $2 \mathrm{~m}^{2}$ at depths of 5 and $15 \mathrm{~cm}$ in rural and urban regions.

The soil samples were dried in an oven at $60^{\circ} \mathrm{C}$, ground and homogenized using a pestle and mortar (decontaminated).

\section{Extraction of pseudo-total $\mathrm{Cu}$ and Fe}

For pseudo-total $\mathrm{Cu}$ and Fe determination by F AAS, the soil samples were submitted to two different extraction procedures in thermostatic bath $\left(\mathrm{HNO}_{3}+\mathrm{H}_{2} \mathrm{O}_{2}\right.$ or $\left.\mathrm{HNO}_{3}+3 \mathrm{HCl}\right)$ to evaluate the efficiency of $\mathrm{Cu}$ and Fe extraction.

In the first extraction procedure evaluated, $50 \mathrm{~mL}$ of $\mathrm{HNO}_{3}+3 \mathrm{HCl}$ solution was prepared adding 12.5 $\mathrm{mL}$ of $\mathrm{HCl} 37 \%\left(\mathrm{v} \mathrm{v}^{-1}\right)$ and $3.6 \mathrm{~mL}$ of $\mathrm{HNO}_{3} 65 \%\left(\mathrm{w} \mathrm{v}^{-1}\right)$ to a polypropylene tube and filled with deionized water. The $\mathrm{HNO}_{3}+3 \mathrm{HCl}$ solution was stored at $4{ }^{\circ} \mathrm{C}$ for later use for sample digestion. In this way, 7 $\mathrm{mL}$ of $\mathrm{HNO}_{3}+3 \mathrm{HCl}$ and $0.5 \mathrm{~mL}$ of deionized water were added to $0.750 \mathrm{~g}$ of samples and heated in a thermostatic bath at $90{ }^{\circ} \mathrm{C}$ for 2 hours, followed by centrifugation at $4000 \mathrm{rpm}$ for $10 \mathrm{~min}[25,26]$. After the extraction, the final volume was completed to $15 \mathrm{~mL}$ with deionized water.

In the second extraction procedure evaluated, a volume of $3 \mathrm{~mL}$ of $\mathrm{HNO}_{3}$ was added to $0.750 \mathrm{~g}$ of samples. The mixture was heated in a thermostatic bath at $80^{\circ} \mathrm{C}$ for 30 minutes, followed by addition of $2 \mathrm{~mL}$ of $\mathrm{H}_{2} \mathrm{O}_{2}$, heating for 30 minutes, and centrifugation at $4000 \mathrm{rpm}$ for $10 \mathrm{~min}$. After the extraction, the final volume was completed to $10 \mathrm{~mL}$ with deionized water.

\section{Fractionation of $\mathrm{Cu}$ and $\mathrm{Fe}$}

For the Fe and Cu fractionation in different soil samples, the Tessier's extraction method [15] was performed in five sequential extractions steps described below. At the end of each step of the sequential extraction procedure, the samples were submitted to centrifugation at $4000 \mathrm{rpm}$ for 10 min for separation of residue and supernatant. The supernatants were subjected to elemental determination by $F$ AAS or GF AAS.

(i) Exchangeable: The soil samples (ca. $1.0 \mathrm{~g}$ ) were subjected to extraction with $8 \mathrm{~mL}$ of $\mathrm{MgCl}_{2}(1 \mathrm{~mol}$ $\mathrm{L}^{-1}, \mathrm{pH}$ 7.0) under shaking for 1 hour at room temperature, and centrifugation at $4000 \mathrm{rpm}$ for $10 \mathrm{~min}$. After the extraction, the final volume was completed to $10 \mathrm{~mL}$ with deionized water.

(ii) Bound to carbonates: To the residue from step (i), $8 \mathrm{~mL}$ of $\mathrm{CH}_{3} \mathrm{COONa}_{3} \mathrm{H}_{2} \mathrm{O}(1 \mathrm{~mol} \mathrm{~L}-1, \mathrm{pH} 5.0$ adjusted with $\mathrm{CH}_{3} \mathrm{COOH}$ ) was added under continuous agitation for 5 hours at room temperature, and centrifugation at $4000 \mathrm{rpm}$ for 10 minutes. After the extraction, the final volume was completed to 10 $\mathrm{mL}$ with deionized water.

(iii) Bound to Fe-Mn oxides: The residue from step (ii) was extracted with $20 \mathrm{~mL}$ of $\mathrm{NH}_{2} \mathrm{OH}$. $\mathrm{HCl}$ in $25 \%\left(\mathrm{~V} \mathrm{v}^{-1}\right) \mathrm{CH}_{3} \mathrm{COOH}$, under continuous agitation for 6 hours at $96{ }^{\circ} \mathrm{C}$, and centrifugation at $4000 \mathrm{rpm}$ for $10 \mathrm{~min}$. After the extraction, the final volume was completed to $15 \mathrm{~mL}$ with deionized water.

(iv) Bound to organic matter: To the residue from step (iii), $\mathrm{HNO}_{3}\left(3 \mathrm{~mL}, 0.02 \mathrm{~mol} \mathrm{~L}^{-1}\right)$ and $\mathrm{H}_{2} \mathrm{O}_{2}(5 \mathrm{~mL}$, $\left.30 \%\left(\mathrm{~V} \mathrm{~V}^{-1}\right)\right)$ were added, adjusted to $\mathrm{pH} 2$ with $\mathrm{HNO}_{3}$, and the mixture was heated to $85^{\circ} \mathrm{C}$ for 2 hours under continuous agitation. A second aliquot of $3 \mathrm{~mL}$ of $30 \%\left(\mathrm{v} \mathrm{v}^{-1}\right) \mathrm{H}_{2} \mathrm{O}_{2}\left(\mathrm{pH} 2.0\right.$ adjusted with $\left.\mathrm{HNO}_{3}\right)$ was then added and the sample was heated again to $85^{\circ} \mathrm{C}$ for 3 hours under continuous agitation. After cooling, $\mathrm{CH}_{3} \mathrm{COONH}_{4}\left(5 \mathrm{~mL}, 3.2 \mathrm{~mol} \mathrm{~L}^{-1}\right)$ in $20 \%\left(\mathrm{v} \mathrm{v}^{-1}\right) \mathrm{HNO}_{3}$ was added and the sample was diluted to $20 \mathrm{~mL}$ and agitated continuously for 30 minutes, and centrifuged at $4000 \mathrm{rpm}$ for $10 \mathrm{~min}$. After the extraction, the final volume was completed to $10 \mathrm{~mL}$ with deionized water.

(v) Residual: The residue from step (iv) was digested with $\mathrm{HNO}_{3}$ and $\mathrm{H}_{2} \mathrm{O}_{2}$ mixture according to the 
procedure previously described for pseudo-total Fe and $\mathrm{Cu}$ determination. After the extraction, the final volume was completed to $6 \mathrm{~mL}$ with deionized water.

\section{$\mathrm{Cu}$ and Fe determination}

The determination of $\mathrm{Cu}$ (pseudo-total) and Fe (pseudo-total and fractioned) was carried out by $\mathrm{F}$ AAS, and $\mathrm{Cu}$ (fractioned) by GF AAS.

For elemental determination by F AAS, acetylene flow was optimized, ranging from 50 to $80 \mathrm{~L} \mathrm{~h}^{-1}$ in increments of $5 \mathrm{~L} \mathrm{~h}^{-1}$, with constant air flow $\left(430 \mathrm{~L} \mathrm{~h}^{-1}\right)$ and observation height $(6 \mathrm{~mm})$. The observation height was evaluated $(5,8,10,12$, and $15 \mathrm{~mm})$ in the best acetylene flow for each element. Under each condition, absorbance signals were obtained in triplicate, using analytical solutions of 0.75 and 1.0 $\mathrm{mg} \mathrm{L}^{-1}$ of $\mathrm{Fe}$ and $\mathrm{Cu}$, respectively. Instrument calibration was performed using analytical solutions with concentrations ranging from 0.25 to $3.0 \mathrm{mg} \mathrm{L}^{-1}$ and 0.1 to $4.0 \mathrm{mg} \mathrm{L}^{-1}$ in $0.1 \%\left(\mathrm{v} \mathrm{v}^{-1}\right) \mathrm{HNO}_{3}$ for Fe and $\mathrm{Cu}$, respectively. For the $\mathrm{Fe}$ determination, further dilutions with deionized water were necessary, ranging from 2 (bound to carbonates fraction) to 500 -fold (residual fraction).

The fractionated $\mathrm{Cu}$ determination was carried out by GF AAS in different extracts. The instrument calibration was performed using analytical solutions with concentrations ranging from 10 to $80 \mu \mathrm{L} \mathrm{L}^{-1}$ of $\mathrm{Cu}$ in $0.1 \% \mathrm{v} \mathrm{v}^{-1} \mathrm{HNO}_{3}$. For the $\mathrm{Cu}$ determination, the supernatants were diluted 2- to 100-fold in deionized water and no chemical modifier was used.

The chemical interferences during $\mathrm{Cu}$ and Fe determination were verified by an addition and recovery test, adding $0.4 \mathrm{mg} \mathrm{L}^{-1}$ of $\mathrm{Fe}$ (pseudo-total and different extracts) or $\mathrm{Cu}$ (pseudo-total), and $20 \mathrm{\mu g} \mathrm{L}^{-1}$ of $\mathrm{Cu}$ (different fractionation extracts).

\section{Statistical analyses}

The determination of the pseudo-total concentration and fractionated was done in triplicate for the soil from the rural and urban areas with different depths.

Statistically significant differences $(p<0.05)$ between the soil origin or depth in a given element and extraction procedure were detected using two-way analysis of variance (ANOVA). Differences between means were compared by Student's $t$-test at the $95 \%$ confidence limit. Similarly, the statistically significant differences $(p<0.05)$ between the soil origin or depth in a given element and step of the fractionated extracts were detected using Student's $t$-test at the 95\% confidence limit.

\section{RESULTS AND DISCUSSION}

\section{Optimization of flame conditions for Fe and Cu determination by FAAS}

A suitable chemical environment of the air-acetylene flame is required for proper formation of the atomic precursors, since different flame compositions may favor the refractory species formation of the elements [27]. The effects of the acetylene flow variation on $\mathrm{Cu}$ and Fe atomization are shown in Figure 1. In general, it was verified that increased fuel flow altered $\mathrm{Cu}$ atomization and its absorbance decreased significantly taking into account the profile and standard deviation of the absorbance value $(n=3)$. On the other hand, Fe showed significant increase in absorbance value from $70 \mathrm{~L} \mathrm{~h}^{-1}$. Thus, the acetylene flow of 50 and $70 \mathrm{~L} \mathrm{~h}^{-1}$ were applied in the $\mathrm{Cu}$ and Fe determination, respectively.

After fuel flow optimization, observation height was also optimized to obtain the highest values of absorbance, which represent the interaction of the electromagnetic radiation from the hollow cathode lamp with gaseous atoms in the fundamental state formed in the atomizer [27]. The effects of the observation height variation on the $\mathrm{Cu}$ and $\mathrm{Fe}$ absorbance values are shown in Figure 1. It was found that the absorbance value decreased with increasing observation height, thus, the observation height of $5 \mathrm{~mm}$ was applied in the $\mathrm{Cu}$ and Fe determination in the samples considering the profile and standard deviation of the absorbance signal $(n=3)$. 

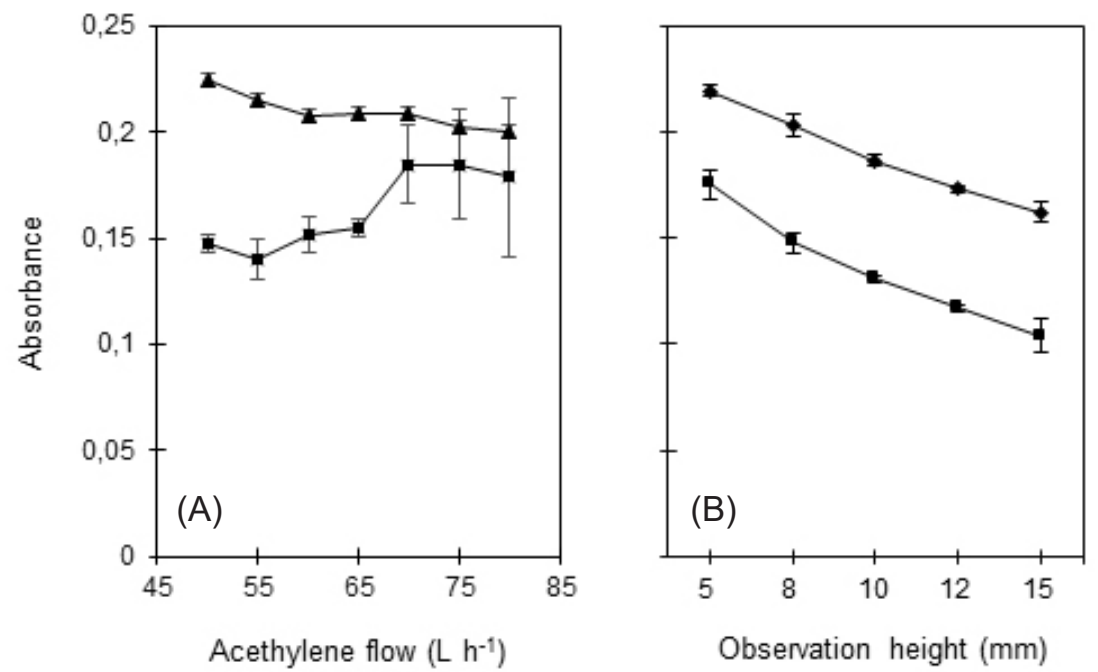

Figure 1. Optimization of flame chemical composition (acetylene flow) (A) and observation height (B) using analytical solutions of $1.0 \mathrm{mg} \mathrm{L}^{-1} \mathrm{Cu}(\mathbf{\Delta})$ and $0.75 \mathrm{mg} \mathrm{L}^{-1} \mathrm{Fe}(\mathbf{})$.

Characteristic parameters of the analytical calibration curve for $\mathrm{Cu}$ and Fe determination by $\mathrm{F}$ AAS, such as linear range, correlation coefficient $\left(R^{2}\right)$, limit of detection (LOD), and limit of quantification (LOQ), are presented in Table II. The LOD was calculated using the standard deviation of 10 measurements of the analytical blank sample $\left(3 \times \sigma_{\text {blank }}\right.$, where $\sigma$ is the standard deviation) and the LOQ was calculated as $3.3 \times$ LOD. The LOD and LOQ values were obtained in $\mu \mathrm{g} \mathrm{g}^{-1}$, considering a sample mass of $0.75 \mathrm{~g}$ and a final volume of $10 \mathrm{~mL}$ for the solutions.

The influence of concomitants in pseudo-total $\mathrm{Cu}$ and Fe determination by F AAS was investigated through addition and recovery test, adding to the samples $0.4 \mathrm{mg} \mathrm{L}^{-1}$ of $\mathrm{Fe}$ and $\mathrm{Cu}$ after the extraction procedures $\left(\mathrm{HNO}_{3}+\mathrm{H}_{2} \mathrm{O}_{2}\right.$ or $\left.\mathrm{HNO}_{3}+3 \mathrm{HCl}\right)$. The $\mathrm{Cu}$ and $\mathrm{Fe}$ recovery percentages in different extractants are shown in Table II. The recoveries showed absence of matrix influence in $\mathrm{Cu}$ and Fe determination with recovery percentages ranging from 98 to 107\%. According to NBR ISO/IEC 17025, guidelines for elemental determination by spectrometric techniques, the recovery tolerance should range from 70 to $120 \%[28]$.

Table II. Characteristics method for $\mathrm{Cu}$ and Fe determination by F AAS

\begin{tabular}{lcccccc}
\hline Element & $\begin{array}{c}\text { Linear range } \\
\left.(\mathbf{m g ~ L})^{-1}\right)\end{array}$ & $\mathbf{R}^{\mathbf{2}}$ & $\begin{array}{c}\text { Analytical } \\
\text { blank }\end{array}$ & $\begin{array}{c}\text { LOD } \\
\left(\boldsymbol{\mu} \mathbf{g ~ g}^{-1}\right)\end{array}$ & $\begin{array}{c}\text { LOQ } \\
\left(\boldsymbol{\mu} \mathbf{g ~ g}^{-1}\right)\end{array}$ & $\begin{array}{c}\text { Recovery } \\
(\%)\end{array}$ \\
\hline $\mathrm{Cu}$ & $0.1-4.0$ & 0.9995 & $\mathrm{HNO}_{3}+3 \mathrm{HCl}$ & 5 & 15 & 101 \\
& \multirow{2}{*}{$\mathrm{HNO}+\mathrm{H}_{2} \mathrm{O}_{2}$} & 0.04 & 0.1 & 107 \\
\hline \multirow{2}{*}{$\mathrm{Fe}$} & $0.25-3.0$ & 0.9993 & $\mathrm{HNO}_{3}+213 \mathrm{HCl}$ & 0.03 & 0.1 & 99 \\
& & & $\mathrm{HNO}_{3}+\mathrm{H}_{2} \mathrm{O}_{2}$ & 0.4 & 1.2 & 98 \\
\hline
\end{tabular}

\section{Accumulation $\mathrm{Fe}$ and $\mathrm{Cu}$ in rural and urban soils}

The Fe and $\mathrm{Cu}$ concentrations in soil samples from the rural and urban areas, and at depths of 5 and $15 \mathrm{~cm}$ obtained after the different extraction procedures are shown in Table III. 
Table III. Fe and Cu concentrations in soils submitted to different extraction procedures

\begin{tabular}{lcccc}
\hline \multirow{2}{*}{$\begin{array}{l}\text { Soil Origin I } \\
\text { Depth }\end{array}$} & \multicolumn{3}{c}{ Elemental concentration \pm standard deviation $(\mathrm{n}=3)$} \\
\cline { 2 - 5 } & $\mathrm{HNO}_{3}+\mathrm{H}_{2} \mathrm{O}_{2}$ & $\mathrm{HNO}_{3}+3 \mathrm{HCl}$ & $\mathrm{HNO}_{3}+\mathrm{H}_{2} \mathrm{O}_{2}$ & $\mathrm{HNO}_{3}+3 \mathrm{HCl}$ \\
\hline rural / $5 \mathrm{~cm}$ & $0.7 \pm 0.1^{\mathrm{a}}$ & $2.1 \pm 0.4^{\mathrm{a}}$ & $4.8 \pm 0.1^{\mathrm{a}}$ & $13 \pm 1^{\mathrm{a}}$ \\
rural / $15 \mathrm{~cm}$ & $0.9 \pm 0.1^{\mathrm{a}}$ & $3.4 \pm 0.2^{\mathrm{a}}$ & $6.7 \pm 0.2^{\mathrm{a}}$ & $14 \pm 1^{\mathrm{a}}$ \\
urban / $5 \mathrm{~cm}$ & $9.6 \pm 0.6^{\mathrm{b}}$ & $10 \pm 2^{\mathrm{b}}$ & $10 \pm 1^{\mathrm{b}}$ & $25 \pm 2^{\mathrm{b}}$ \\
urban / $15 \mathrm{~cm}$ & $9.5 \pm 0.5^{\mathrm{b}}$ & $13 \pm 1^{\mathrm{b}}$ & $10 \pm 1^{\mathrm{b}}$ & $25 \pm 2^{\mathrm{b}}$ \\
\hline
\end{tabular}

${ }^{*} \mathrm{mg} \mathrm{kg}^{-1} ;{ }^{* *} \mathrm{~g} \mathrm{~kg}^{-1}$; ${ }^{\mathrm{a}-\mathrm{b}}$ Different superscripted letters in a given element and extraction procedure indicate significant differences in elemental concentration between depths and origins $(p<0.05)$.

The extraction procedures for pseudo-total $\mathrm{Cu}$ and Fe determination may have promoted the $\mathrm{Cu}$ and Fe partial extraction, since that the solubilization was not complete. It was observed that the concentrations obtained using $\mathrm{HNO}_{3}+3 \mathrm{HCl}$ were significantly higher when compared to the mixture $\mathrm{HNO}_{3}+\mathrm{H}_{2} \mathrm{O}_{2}$, since that more acidic medium and the $\mathrm{HCl}$ presence has complexing character, resulting in a greater solubility of compounds bound to $\mathrm{Cu}$ and $\mathrm{Fe}$ [29]. On the other hand, the procedure with $\mathrm{HNO}_{3}+\mathrm{H}_{2} \mathrm{O}_{2}$ was more feasible, because the mixture $\mathrm{HNO}_{3}+3 \mathrm{HCl}$ promoted several problems in the control of the solution boiling in thermostatic bath, due to violent reaction with great gas generation and possible sample losses during the process. Therefore, the residual fraction from fractionation procedure by the Tessier's method was solubilized using $\mathrm{HNO}_{3}+\mathrm{H}_{2} \mathrm{O}_{2}$ and only this extraction procedure for pseudo-total elemental determination was considered.

The different depths were evaluated aiming to analyze recent changes $(5 \mathrm{~cm})$, as well as, environmental changes in other periods $(15 \mathrm{~cm})$ and according to the Table III there were no significant differences in the pseudo-total $\mathrm{Fe}$ and $\mathrm{Cu}$ concentration in soils collected at different depths. However, the average $\mathrm{Cu}$ and $\mathrm{Fe}$ concentration in the soil from the urban area were significantly higher than rural area, varying from approximately $12(\mathrm{Fe})$ to $2(\mathrm{Cu})$ times higher. The rural area is remote and environmental preservation region, while urban region has become a storage area for building materials and other wastes with sewage passage. In this way, anthropogenic actions may be a determining factor for the increase of total $\mathrm{Fe}$ and $\mathrm{Cu}$ concentration in the urban area evaluated.

The $\mathrm{Cu}$ concentrations in the urban region were 13.7 and 10.6 times higher than in the rural region at depths of $5 \mathrm{~cm}$ and $15 \mathrm{~cm}$, respectively, while Fe concentrations were 2.0 and 1.5 times higher than in the rural region. Therefore, these results in urban soils showed the effects of anthropic action and industrial activities on the accumulation of $\mathrm{Fe}$ and $\mathrm{Cu}$ in the soil [30]. In addition, although $\mathrm{Cu}$ concentrations are below the values established by CONAMA resolution 420/2009 $\left(600 \mathrm{mg} \mathrm{kg}^{-1}\right.$ in industrial areas), it was verified that the anthropic actions in region are favoring the increase in the these metals concentration in the soil, which can be easily accumulated and, in the future, may result in potential problems such as toxicity to plants and animals [4].

\section{Fractionation of $\mathrm{Fe}$ and $\mathrm{Cu}$ in rural and urban soils}

Characteristic parameters of the analytical calibration curve for $\mathrm{Cu}$ and Fe determination by GF AAS and F AAS, respectively, are presented in Table IV. The LOD and LOQ values were obtained in $\mathrm{ng} \mathrm{g}^{-1}$, considering a sample mass of $1.0 \mathrm{~g}$ and a final volume of $10 \mathrm{~mL}$ (step 1 and 2 of the sequential extraction) and $15 \mathrm{~mL}$ (step 3 and 4 of the sequential extraction) for the solutions.

The concomitants influence in fractionated $\mathrm{Cu}$ and $\mathrm{Fe}$ determination was investigated through addition and recovery test. The $\mathrm{Cu}$ and Fe recovery percentages in different extractants are shown in Table IV. The recoveries showed absence of matrix influence in $\mathrm{Cu}$ and Fe determination with recovery 
percentage ranging from 87 to $115 \%$ [28].

Table IV. Characteristics method for fractionated Cu and Fe determination and recovery evaluation in different steps of Tessier's method

\begin{tabular}{|c|c|c|c|c|c|c|}
\hline Element & Linear range & $\mathbf{R}^{2}$ & Analytical blank & LOD & LOQ & Recovery (\%) \\
\hline & & & Step 1 & 3.7 & 12.1 & 93 \\
\hline & & & Step 2 & 1.5 & 4.9 & 115 \\
\hline \multirow[t]{5}{*}{$\mathrm{Cu}^{*}$} & $10-80$ & 0.9998 & Step 3 & 6.6 & 21.8 & 98 \\
\hline & & & Step 4 & 19.3 & 66.7 & 99 \\
\hline & & & Step 5 & 21.3 & 70.4 & 114 \\
\hline & & & Step 1 & 0.8 & 2.6 & 87 \\
\hline & & & Step 2 & 1.7 & 5.1 & 91 \\
\hline \multirow[t]{3}{*}{$\mathrm{Fe}^{* *}$} & $0.25-3.0$ & 0.9961 & Step 3 & 0.5 & 1.5 & 88 \\
\hline & & & Step 4 & 0.6 & 1.7 & 92 \\
\hline & & & Step 5 & 0.4 & 1.2 & 98 \\
\hline
\end{tabular}

*Linear range $\left(\mu \mathrm{g} \mathrm{L}^{-1}\right)$; LOD and LOQ $\left(\mathrm{ng} \mathrm{g}^{-1}\right)$

${ }^{* *}$ Linear range $\left(\mathrm{mg} \mathrm{L}^{-1}\right)$; LOD and LOQ $\left(\mu \mathrm{g} \mathrm{g}^{-1}\right)$

The $\mathrm{Cu}$ and $\mathrm{Fe}$ concentrations in five fractions of the sequential extraction of the Tessier's method applied to the soil samples from rural and urban areas at different depths are presented in Table V, as well as, the elemental concentration in the residual fraction after the extraction procedure with $\mathrm{HNO}_{3}+$ $\mathrm{H}_{2} \mathrm{O}_{2}$ and the sum of the elemental concentration at all steps.

Table V. Fe and Cu concentrations in soils submitted to sequential extraction procedures of Tessier's method

\begin{tabular}{|c|c|c|c|c|c|c|c|}
\hline & \multirow{2}{*}{$\begin{array}{l}\text { Soil origin/ } \\
\text { Depth }\end{array}$} & \multicolumn{5}{|c|}{ Concentration \pm standard deviation $(n=3)$} & \multirow[b]{2}{*}{ Sum } \\
\hline & & Step 1 & Step 2 & Step 3 & Step 4 & Step 5 & \\
\hline \multirow{4}{*}{$\mathrm{Cu}^{*}$} & $\begin{array}{l}\text { Rural } \\
5 \mathrm{~cm}\end{array}$ & $<$ LOD & $<\mathrm{LOQ}$ & $28 \pm 2^{a}$ & $0.40 \pm 0.04^{a}$ & $0.19 \pm 0.04^{a}$ & $0.6 \pm 0.2^{a}$ \\
\hline & $\begin{array}{l}\text { Rural } \\
15 \mathrm{~cm}\end{array}$ & $330 \pm 10^{a}$ & $110 \pm 1^{a}$ & $29 \pm 2^{\mathrm{a}}$ & $0.34 \pm 0.05^{a}$ & $0.18 \pm 0.02^{a}$ & $0.9 \pm 0.1^{a}$ \\
\hline & $\begin{array}{l}\text { Urban } \\
5 \mathrm{~cm}\end{array}$ & $310 \pm 13^{a}$ & $570 \pm 2^{b}$ & $919 \pm 28^{b}$ & $2.5 \pm 0.2^{\mathrm{b}}$ & $4.7 \pm 0.1^{\mathrm{b}}$ & $8.9 \pm 0.2^{b}$ \\
\hline & $\begin{array}{l}\text { Urban } \\
15 \mathrm{~cm}\end{array}$ & $212 \pm 7^{b}$ & $410 \pm 4^{c}$ & $902 \pm 9^{b}$ & $2.4 \pm 0.1^{b}$ & $4.9 \pm 0.3^{b}$ & $8.8 \pm 0.3^{b}$ \\
\hline \multirow{4}{*}{$\mathrm{Fe}^{* *}$} & $\begin{array}{l}\text { Rural } \\
5 \mathrm{~cm}\end{array}$ & $6.7 \pm 0.6^{a}$ & $60 \pm 5^{a}$ & $230 \pm 10^{a}$ & $420 \pm 10^{a}$ & $3.4 \pm 0.1^{a}$ & $4.2 \pm 0.1^{a}$ \\
\hline & $\begin{array}{l}\text { Rural } \\
15 \mathrm{~cm}\end{array}$ & $4.7 \pm 0.5^{\mathrm{b}}$ & $40 \pm 2^{\mathrm{b}}$ & $190 \pm 10^{b}$ & $410 \pm 10^{a}$ & $4.9 \pm 0.2^{b}$ & $5.6 \pm 0.2^{b}$ \\
\hline & $\begin{array}{l}\text { Urban } \\
5 \mathrm{~cm}\end{array}$ & $4.7 \pm 0.5^{b}$ & $20 \pm 3^{c}$ & $280 \pm 10^{c}$ & $740 \pm 20^{b}$ & $9.6 \pm 0.4^{c}$ & $11 \pm 1^{c}$ \\
\hline & $\begin{array}{l}\text { Urban } \\
15 \mathrm{~cm}\end{array}$ & $5.9 \pm 0.4^{a}$ & $30 \pm 2^{d}$ & $380 \pm 10^{d}$ & $710 \pm 20^{b}$ & $10 \pm 1^{c}$ & $11 \pm 1^{c}$ \\
\hline
\end{tabular}

${ }^{*}$ Cu concentration in steps 1,2 , and $3\left(\mu \mathrm{g} \mathrm{kg}^{-1}\right)$ and steps 4,5 and sum $\left(\mathrm{mg} \mathrm{kg}^{-1}\right)$

${ }^{* *}$ Fe concentration in steps $1,2,3$, and $4\left(\mathrm{mg} \mathrm{kg}^{-1}\right)$ and step 5 and sum $\left(\mathrm{g} \mathrm{kg}^{-1}\right)$

${ }^{a-d}$ Different superscripted letters in a given element and step indicate significant differences in elemental concentration between depths and origins $(p<0.05)$ 
Firstly, comparing the sum of the $\mathrm{Cu}$ or $\mathrm{Fe}$ concentrations of all fractions with the pseudo-total concentration obtained after the extraction procedure with $\mathrm{HNO}_{3}+\mathrm{H}_{2} \mathrm{O}_{2}$ (Table III), it was verified that $\mathrm{Cu}$ and Fe pseudo-total concentrations were satisfactorily fractionated by Tessier's method.

In addition to indicating a higher solubility of the species bound to $\mathrm{Cu}$ and Fe in more acidic media comparing different extraction procedures, it was possible to infer about each elemental species concentration in the soil through elemental fractionation. The $\mathrm{Cu}$ and Fe distribution showed similar patterns for each sample, which followed order residual $>$ bound to organic matter > bound to Fe-Mn oxides > bound to carbonates > exchangeable. However, rural soil $(15 \mathrm{~cm})$ was an exception to the observed pattern, which contained $200 \%$ more $\mathrm{Cu}$ exchangeable species than bound to carbonates species. Besides that, the Cu species concentration bound to organic matter in rural soil was $110 \%$ (5 $\mathrm{cm})$ and $89 \%(15 \mathrm{~cm})$ higher than residual fraction. In contrast to that observed for the rural soil, in the urban soil the residual fraction presented the highest $\mathrm{Cu}$ concentration.

The Tessier's method fractionation allows to evaluate the metals extraction from different geochemical fractions of the soils and sediments. The first steps of the method extract from the sample the weakly associated and most available metals, while in the residual fraction, it is possible to assess the metal fraction that is not potentially available to the environment and is accumulated in the soil under natural conditions, such as metals included in clays $[15,18]$. Thus, it is possible to infer that soil samples from urban areas are polluted samples, since that in polluted soils there are high residual content, evidencing by incomplete dissolution during previous steps of the Tessier's method $[15,18]$ and the residual fraction (Table V, step 5) shows the high metals accumulation and low reactivity of Cu species present in urban soil.

The $\mathrm{Cu}$ concentration exchangeable and bound to carbonates in the rural soil collected at the depth of $15 \mathrm{~cm}$ is significantly higher in relation to the depth of $5 \mathrm{~cm}$, while there is no significant difference between $\mathrm{Cu}$ concentrations bound to Fe-Mn oxides, bound to organic matter, and residual at both depths evaluated. Furthermore, with increasing $\mathrm{Cu}$ concentrations exchangeable and bound to carbonates (fractions 1 and 2) in $15 \mathrm{~cm}$, it is possible to infer that weathering, such as changes in the local vegetation or $\mathrm{Cu}$ redistribution by wind or water action promoted a decrease in concentration of mobile and bioavailable $\mathrm{Cu}$ species in upper layers of rural soil. On the other hand, unlike that observed in the rural area, in the urban area the fractions of $\mathrm{Cu}$ exchangeable (fraction 1) and bound to carbonates (fraction 2) decreased significantly with the depth increase, in which it was possible to infer that current anthropic activities favor the increase of $\mathrm{Cu}$ species concentration more mobile and bioavailable in the topsoil. In the residue (fraction 5) there is Cu species incorporated into soil minerals and appeared to be the most inactive did not change significantly with depth in both soils [19].

In contrast to that observed for $\mathrm{Cu}$ in rural soils, at greater depths there is a significant decrease in the exchangeable, bound to carbonates, and bound to Fe-Mn oxides Fe concentration, while there is an increase of $44 \%$ in residual Fe concentration with increasing depth. These results indicate that factors related to weathering have probably increased the concentration of more mobile and bioaccessible species in the topsoil of rural region. The increase in residual Fe concentration corresponds to less mobile and reactive species indicates the Fe accumulation in lower layers of the soil. However, in the urban soil there was a significant increase in the concentration of exchangeable Fe, bound to carbonates and bound to Fe-Mn oxides with increasing depth. The increase in the concentration of these more mobile species in lower layers of the urban soil indicates that anthropic activities in the past favored the increase of these mobile and bioavailable species, which can crystallize into crystalline lattice of soil minerals and compose the residual fraction [18,19].

Additionally, it was observed that significant $\mathrm{Cu}$ and $\mathrm{Fe}$ amounts were associated with the residual fraction, ranging from $20 \%$ (Cu: rural, $15 \mathrm{~cm}$ ) to $91 \%$ (Fe: urban, $15 \mathrm{~cm}$ ) in relation to the pseudo-total concentration. Therefore, Fe fractionation was dominated by residual species as might be expected for an element whose minerals constitute a major structural component of soil [1], ranging from (3.4 \pm 0.1$)$ (rural, $5 \mathrm{~cm}$ ) to $(10 \pm 1$ ) (urban, $15 \mathrm{~cm}$ ) g kg-1 with lower concentrations of exchangeable species ranging from $(4.7 \pm 0.5)$ (rural, $15 \mathrm{~cm}$ ) to $(6.7 \pm 0.6)$ (rural, $5 \mathrm{~cm}$ ) mg kg-1. Indeed, the variable pseudo-total Fe 
and $\mathrm{Cu}$ concentrations were found in the rural and urban soils at different depths, but the exchangeable$\mathrm{Cu}$ and Fe concentrations were relatively low (average $<5 \%$ ), indicating the predominant presence of recalcitrant fractions (associated with Fe-Mn oxides, organic matter, and residual) with low mobile and strongly bound species that favor the accumulation of these elements in the soils, since that $\mathrm{Cu}$ and Fe bound to residual fraction is often consider unreactive and not affected by environmental changes $[18,23]$.

\section{CONCLUSIONS}

The evaluation of the pseudo-total $\mathrm{Cu}$ and Fe concentration in the soils through procedures of partial solubilization showed that there is a significant difference in the content of these elements between different studied soils. The $\mathrm{Cu}$ and Fe concentration in the soil from the urban area were significantly higher than rural area. The high levels of these elements from the urban area must be related to the anthropic activities practiced in this area, which has become a place where the sewage water passes besides being a deposit of construction materials and garbage, while the rural area evaluated is a place of environmental preservation.

Therefore, it was possible to evaluate the potential effects of anthropic activities on the heavy metal concentrations in the soil through fractionation, in which the concentration of exchangeable species of both metals was significantly lower when compared to the concentrations of species bound to organic matter and residual fraction. The results indicated that in addition to be a determining factor and increasing the $\mathrm{Cu}$ and $\mathrm{Fe}$ pseudo-total concentration in the soil, the anthropic actions increased the concentration of these metals associated to residual fraction where metals most strongly associated with soil components, such as metals included in clays.

Finally, in the urban area, the metals evaluated presented lower mobility in the environment and possibly are accumulated in soil under natural conditions. The strong interaction of these metals with soil components and low availability may cause changes in the microorganisms and plant community that share the common environment and interact with each other, animal populations, and the physical environment.

\section{Acknowledgments}

Aline Pereira de Oliveira (2015/01128-6, 2017/05009-7 and 2019/00663-6) and Juliana Naozuka (2015/15510-0 and 2018/06332-9) thank the "Fundação de Amparo à Pesquisa do Estado de São Paulo"/FAPESP for the fellowship provided and financial support, respectively. The authors also thank the "Coordenação de Aperfeiçoamento de Pessoal de Nível Superior"/CAPES for financial support to Graduate Program in Chemistry Sustainability Science and Technology.

\section{Compliance with Ethics Requirements}

The authors declare that they have no conflict of interest. This article does not contain any studies with human or animal subjects.

Manuscript received: June 4, 2019; revised manuscript received: September 6, 2019; manuscript accepted: September 12, 2019; published online: October 18, 2019.

\section{REFERENCES}

1. Wu, S.; Peng, S.; Zhang, X.; Wu, D.; Luo, W.; Zhang, T.; Wu, L. J Geochem Explor., 2015, 148, pp 71-78.

2. Nazir, R.; Khan, M.; Masab, M.; Rehman, H. U.; Rauf, N. U.; Shahab, S.; Shaheen, Z. J. Pharm. Sci. Res., 2015, 7 (3), pp 89-97.

3. Cui, J. L.; Luo, C. L.; Tang, C. W. Y.; Chan, T. S.; Li, X. D. J. Hazard. Mater., 2017, 329, pp 150-158. 
4. Pandey, G.; \& Madhuri, S. Research Journal of Animal, Veterinary and Fishery Sciences, 2014, 2 (2), pp 17-23.

5. Fujimori, T.; Takigami, H. Environ. Geochem. Health., 2014, 36 (1), pp 159-168.

6. Antoniadis, V.; Levizou, E.; Shaheen, S. M.; Ok, Y. S.; Sebastian, A.; Baum, C.; Rinklebe, J. EarthSci. Rev., 2017, 171, pp 621-645.

7. Ghazban, F.; Parizanganeh, A.; Zamani, A.; Baniardalan, S. Int. J. Environ. Res., 2018, 12 (6), pp 843-860.

8. Tóth, G.; Hermann, T.; Da Silva, M. R.; Montanarella, L. Environment international, 2016, 88, pp 299-309.

9. http://www.mma.gov.br/port/conama/legiabre.cfm?codlegi=620 [Accessed 30 June 2018].

10. Mishra, J.; Singh, R.; Arora, N. K. Front. Microbiol., 2017, 8, p 1706.

11. Roy, M.; McDonald, L. M. Land Degradation \& Development, 2015, 26 (8), pp 785-792.

12. Alloway, B. J. Heavy metals in soils. Springer, Dordrecht, 2013, p 11.

13. Du, H. Y.; Yu, G. H.; Sun, F. S.; Usman, M.; Goodman, B. A.; Ran, W.; Shen, Q. R. Biogeosciences, 2019, 16 (7), pp 1433-1445.

14. Guigues, S.; Bravin, M. N.; Garnier, C.; Masion, A.; Chevassus-Rosset, C.; Cazevieille, P.; Doelsch, E. Metallomics, 2016, 8 (3), pp 366-376.

15. Tessier, A.; Campbell, P. G.; Bisson, M. Anal. Chem., 1979, 51 (7), pp 844-851.

16. Kim, R. Y.; Yoon, J. K.; Kim, T. S.; Yang, J. E.; Owens, G.; Kim, K. R. Environ. Geochem. Health., 2015, 37 (6), pp 1041-1061.

17. Essington, M. E. Soil and water chemistry: an integrative approach. CRC press. 2015.

18. Bacon, J. R.; Davidson, C. M. Analyst, 2008, 133 (1), pp 25-46.

19. Fajkovic, H.; Roncevic, S.; Nemet, I.; Prohic, E.; Leontic-Vazdar, D. Fractionation of metals by sequential extraction procedures (BCR and Tessier) in soil exposed to fire of wide temperature range. In: EGU General Assembly Conference Abstracts, 2017, 19, p 424.

20. Liu, Y.; Zhang, J.; He, H. Acta Oceanol. Sin., 2018, 37 (5), pp 22-28.

21. Orecchio, S.; Amorello, D.; Barreca, S.; Pettignano, A. Environ. Sci.: Processes Impacts, 2016, 18 (3), pp 323-329.

22. Gabarrón, M.; Zornoza, R.; Martínez-Martínez, S.; Muñoz, V. A.; Faz, Á.; Acosta, J. A. Chemosphere, 2019, 218, pp 266-272.

23. Sungur, A.; Soylak, M.; Yilmaz, E.; Yilmaz, S.; Ozcan, H. Soil and Sediment Contamination: An International Journal, 2015, 24 (1), pp 1-15.

24. Souza, W. M. Influência dos atributos do solo na sorção e lixiviação do indaziflam em solos tropicais. Master's thesis, 2018, Universidade Federal de Viçosa, Minas Gerais, Brazil.

25. Inboonchuay, T.; Suddhiprakarn, A.; Kheoruenromne, I.; Anusontpornperm, S.; Gilkes, R. J. Geoderma Regional, 2016, 7, pp. 120-131.

26. Ferri, R.; Hashim, D.; Smith, D. R.; Guazzetti, S.; Donna, F.; Ferretti, E.; Curatolo, M.; Moneta, C.; Beone, G. M.; Lucchini, R. G. Sci. Total Environ., 2015, 518, pp. 507-517.

27. Skoog, D. A.; West, D. M.; Holler, F. J.; Stanley, R. C. Fundamentos da Química Analítica, Translation of the $8^{\text {th }}$ North-American edition. Ed. Thomson, São Paulo, 2007, p 807.

28. Associação Brasileira de Normas Técnicas. NBR ISO/IEC 17025: Requisitos Gerais para Competência de Laboratórios de Ensaio e Calibração, 2005.

29. Hsu, L. C.; Liu, Y. T.; Tzou, Y. M. J. Hazard. Mater., 2015, 296, pp 230-238.

30. Karim, Z.; Qureshi, B. A.; Mumtaz, M.; Qureshi, S. Ecol. Indic., 2014, 42, pp 20-31. 